\title{
Peningkatan Hasil Belajar Dalam Menganalisis Hubungan Komponen Ekosistem Menggunakan Model Pembelajaran Problem Based Learning Pada Peserta Didik Kelas V
}

\section{ENTIOWATI}

SD Negeri Lomanis 01

entiowatiamar@gmail.com

\section{Article History}

accepted 01/11/2020

approved 08/11/2020

published 15/11/2020

\begin{abstract}
The purpose of this study was to improve learning outcomes in analyzing the relationship between ecosystem components using the problem-based learning (PBL) model in class $v$ students.

This research is a classroom action research (PTK) which is carried out in two cycles, each cycle consisting of planning, implementation, observation, and reflection stages. The subjects of this study were students of class V SD Lomanis 01 in the 2020/2021 academic year, totaling 28 students. Data collection techniques using observation and tests. Data analysis includes data reduction, data presentation, and drawing conclusions. Research shows that the application of the problem-based learning model can improve student learning outcomes in the material of analyzing the relationship of ecosystem components in class V SD Negeri Lomanis 01 in the academic year 2020/2021 as evidenced by the percentage of learning outcomes completeness in cycle I of $43 \%$ to $92 \%$ in the cycle II.
\end{abstract}

\section{Abstrak}

Tujuan penelitian ini adalah meningkatkan hasil belajar dalam menganalisis hubungan komponen ekosistem menggunakan model problem based learning ( PBL ) pada peserta didik kelas v. Penelitian ini merupakan penelitian tindakan kelas (PTK) yang dilaksanakan dalam dua siklus, setiap siklus terdiri dari tahap perencanaan, pelaksanaan, observasi, dan refleksi. Subjek penelitian ini adalah peserta didik kelas V SD Lomanis 01 tahun pelajaran 2020/2021 yang berjumlah 28 peserta didik. Teknik pengumpulan data menggunakan observasi dan tes. Analisis data meliputi reduksi data, penyajian data, dan penarikan kesimpulan. Penelitian menunjukkan bahwa penerapan model pembelajaran problem Based Learning dapat meningkatkan hasil belajar siswa pada materi menganalisis hubungan komponen ekosistem di kelas V SD Negeri Lomanis 01 tahun pelajaran 2020/2021 yang dibuktikan dengan persentase ketuntasan hasil belajar pada siklus I sebesar $43 \%$ menjadi $92 \%$ pada siklus II.

Kata kunci: Problem Based learning, komponen ekosistem,peserta didik

Social, Humanities, and Education Studies (SHEs): Conference Series https://jurnal.uns.ac.id/shes 


\section{PENDAHULUAN}

Hasil belajar peserta didik kelas V SDN Lomanis 01 pada pembelajaran Tema 5 Subtema 2 Pembelajaran 5 mapel IPA sangat rendah. Berdasarkan hasil refleksi pembelajaran pada mapel IPA materi mencermati video pembelajaran, siswa mampu membuat pamflet yang berisi penjelasan simbiosis, menunjukkan hasil yang belum maksimal. Hasil belajar peserta didik masih di bawah tingkat ketuntasan belajar.

Berdasarkan hasil observasi proses pembelajaran Tema 5 Subtema 2 Pembelajaran 5 dan evaluasi terhadap proses pembelajaran, peneliti berhasil merangkum permasalahan yang terjadi dalam pembelajaran, antara lain :

a. Kurangnya perhatian peserta didik terhadap pelajaran.

b. Rendahnya tingkat penguasaan peserta didik terhadap materi pembelajaran yang telah diberikan.

c. Sebagian peserta didik masih belurn dapat menyelesaikan soal-soal latihan dengan baik.

d. Proses pembelajaran kurang efektif, karena belum terjadi interaksi belajar mengajar yang optimal.

e. Peserta didik cenderung pasif.

f. Peserta didik kurang memberi respon terhadap pertanyaan yang diajukan guru.

g. Motivasi belajar peserta didik kurang.

h. Metode dan teknik mengajar tidak variatif, sehingga timbul kejemuan bagi peserta didik.

i. Peserta didik dalam belajar kurang bergairah sehingga timbul kebosanan dalam menerima pelajaran dan guru

Peneliti merumuskan beberapa rumusan masalah antara lain :Bagaimana meningkatkan analisis hubungan komponen ekosistem dengan model pembelajaran Problem Based Leraning ( PBL ) dapat meningkatkan hasil belajar peserta didik dalam pembelajaran Tema 5 Subtema 2 Pembelajaran IPA?

Diharapkan penelitian ini dapat bermanfaat bagi guru, siswa dan sekolah pada pembelajaran Tema 5 Subtema 2 Pembelajaran 5 sebagai berikut :

Bagi Guru :

1. Membantu guru dalam memperbaiki kinerjanya agar terus meningkat.

2. Meningkatkan profesionalisme guru dalam kegiatan belajar mengajar.

Bagi Siswa

1. Meningkatkan minat dan prestasi belajar.

2. Memotivasi Siswa bahwa mata pelajaran IPA bukan mata pelajaran yang sulit. Bagi sekolah

1. Memberikan nilai tambah (value added) yang positif bagi sekolah

2. Mempersiapkan sejak dini lulusan sekolah dengan hasil yang baik. 
SHEs: Conference Series 3 (3) (2020) 371 - 377

PBL atau Problem Base Learning adalah salah satu model pembelajaran Pengertian PBL menurut Dutch (dalam Amir, 2009:27) adalah "metode intruksional yang menantang peserta didik agar belajar untuk belajar bekerjasama dalam kelompok untuk mencari solusi bagi masalah yang nyata". Masalah digunakan untuk mengaitkan rasa keingintahuan, kemampuan analisis, dan inisiatif siswa terhadap materi pelajaran. PBL mempersiapkan peserta didik untuk berpikir kritis dan analitis, dan menggunakan sumber belajar yang sesuai. Sanjaya (2010: 214) mengatakan bahwa pendekatan Problem Based Learning (PBL) adalah rangkaian aktivitas pembelajaran yang menekankan kepada proses penyelesaian masalah yang dihadapi secara ilmiah. Model PBL adalah model pembelajaran yang melatih dan mengembangkan kemampuan dalam menyelesaikan masalah-masalah autentik dari kehidupan nyata siswa, untuk merangsang kemampuan berpikir secara lebih luas Slameto, 2011:7).Selanjutnya PBL diorganisasikan diseputar situasi-situasi kehidupan nyata, yang menolak jawaban-jawaban sederhana dan mengandung solusi yang competing. Supinah (2010:17) mengemukakan bahwa Problem Based Learning sebagai pendekatan pembelajaran yang diawali dengan pemberian masalah kepada siswa dimana masalah tersebut diawali dengan pemberian masalah kepada siswa dimana masalah tersebut dialami atau merupakan pengalaman sehari-hari siswa.

Trianto (2009: 93) bahwa karakteristik model PBL yaitu: (a) adanya pengajuan pertanyaan atau masalah, (b) berfokus pada keterkaitan antar disiplin, (c) penyelidikan autentik, (d) menghasilkan produk atau karya dan mempresentasikannya, dan (e) kerja sama. Ibrahim yang dikutip dalam (Shoimin Aris, 2014:129) kegiatan dalam pembelajaran yang menerapkan Problem Based Learning meliputi mengangkat permasalahan, mengarahkan pada keterkaitan dari beberapa disiplin ilmu, penyelidikan autentik, kerja sama dan menghasilkan karya serta menampilkan hasil. PBL tidak dirancang untuk membantu guru memberikan informasi sebanyakbanyaknya pada siswa.

Berdasarkan penjelasan Trianto (2011: 96-97) Model pembelajaran berdasrkan masalah memiliki kelebihan dan kekurangan. Kelebihan PBL sebagai model pembelajaran adalah: (1) realistic dengan kehidupan siswa; (2) Konsep sesuai denagn kebutuhan siswa; (3) memupuk sifat inquiri siswa; (4) retensi konsep jadi kuat; dan (5) memupuk kemampuan problem solving

PBL antara lain: (1) persiapan pembelajaran (alat, problem, konsep) yang kompleks; (2) sulitnya mencari problem yang relevan; (3) sering terjadi miss-konsepsi; dan (4) konsumsi waktuyang cukup dalam proses penyelidikan. Imas Kurniasih dan Berlin Sani (2015, h.50) diantaranya: a) Model ini butuh pembiasaan, karena model ini cukup rumit dalam teknisnya, serta siswa harus dituntut untuk konsentrasi dan daya kreasi yang tinggi. b) Dengan menggunakan model ini, berarti proses pembelajaran harus dipersiapkan dalam waktu yang cukup panjang. Karena sedapat mungkin setiap persoalan yang akan dipecahkan harus tuntas, agar maknanya tidak terpotong. c) Siswa tidak dapat benar-benar tahu apa yang mungkin penting bagi mereka untuk belajar, terutama bagi mereka yang tidak memiliki pengalaman sebelumnya. d) Sering juga ditemukan kesulitan terletak pada guru, karena guru kesulitan dalam menjadi fasilitator dan mendorong siswa untuk mengajukan pertanyaan yang tepat daripada menyerahkan merek solusi 
SHEs: Conference Series 3 (3) (2020) 371 - 377

\section{METODE}

Penelitian ini merupakan penelitian tindakan kelas (PTK) yang dilaksanakan dalam dua siklus, setiap siklus terdiri dari tahap perencanaan, pelaksanaan, observasi, dan refleksi. Subjek penelitian ini adalah peserta didik kelas V SD Negeri Lomanis 01 tahun pelajaran 2020/2021 yang berjumlah 28 peserta didik. Data yang dianalisis berupa data kualitatif yaitu penggunaan model problem based learning dan data kuantitatif yaitu hasil peserta didik. Teknik pengumpulan data menggunakan tes. Uji validitas data menggunakan Analisis data meliputi reduksi data, penyajian data, dan penarikan kesimpulan

\section{HASIL DAN PEMBAHASAN}

Berdasarkan analisis hasil penelitian yang telah diuraikan maka pembahasan pada penelitian ini sebagai berikut Hasil penelitian menunjukkan peningkatan penerapan model problem based learning dilakukan oleh guru dapat meningkatkan keaktifan siswa

Penerapan Model Problem based learning dalam pembelajaran menganalisis hubungan komponen ekosistem meliputi langkah-langkah:

(1) Peserta didik memperhatikan penjelasan guru terkait tujuan pembelajaran, media yang digunakan, serta mengenalkan masalah dan memotivasi untuk mengenali masalah mencari solusinya

(2) Menglompokan peserta didik ke dalam beberapa kelompok serta memberikan bimbingan terkait pemecahan masalah yang telah diberikan

(3) Peserta didik di ajak untuk menemukan informasi dari berbagai sumber, melakukan penyelidikan dan pemecahan masalah

(4) Peserta didik membuat rencana laporan yang akan disampaikan , berikut dengan dokumentasi yang di rancang dengan model sesuai krativitas masing-masing

Langkah-langkah model problem based learning dilaksanakan dalam penelitian ini sejalan dengan penelitian yang dilakukan oleh Trianto (2009: 93) menjelaskan bahwa karakteristik model PBL yaitu adanya pengajuan pertanyaan atau masalah, berfokus pada keterkaitan antar disiplin, penyelidikan autentik, menghasilkan produk atau karya dan mempresentasikannya, dan kerja sama

Hasil penelitian menunjukkan peningkatan hasil belajar pada materi menganalisis hubungan Komponen Terlihat pada tabel berikut.

Tabel 1. Hasil Rekap Ketuntasan Belajar IPA Siklus Awal, Siklus I, Siklus II

\begin{tabular}{llllll}
\hline \multirow{2}{*}{ No } & \multirow{2}{*}{ Uraian } & \multicolumn{3}{l}{ Siswa yang tuntas } & $\begin{array}{l}\text { Siswa } \\
\text { tuntas }\end{array}$ \\
\cline { 3 - 6 } & & Frekuensi & $\%$ & Frekuensi & $\%$ \\
\hline 1. & Studi Awal & 7 & 25 & 21 & 75 \\
2. & Siklus I & 12 & 43 & 16 & 57 \\
3. & Siklus II & 26 & 92 & 2 & 8 \\
\hline
\end{tabular}

Dari tabel dan keterangan di atas dapat digambarkan dalam diagram berikut 
SHEs: Conference Series 3 (3) (2020) $371-377$

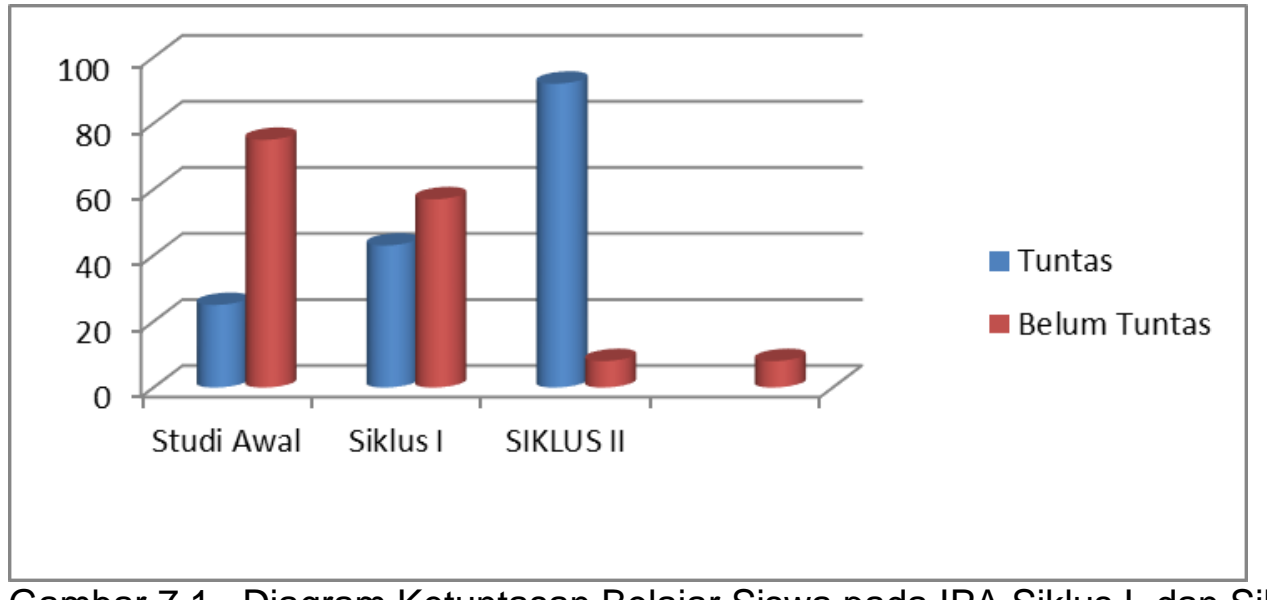

Gambar 7.1. Diagram Ketuntasan Belajar Siswa pada IPA Siklus I, dan Siklus II

Respon keaktifan siswa terhadap implementasi pendekatan ketrampilan proses dalam pembelajaran IPA materi pokok menganalisis hubungan komponen ekosistem terlihat pada tabel berikut ini

Tabel 2. Rekapitulasi Peningkatan Respon Keaktifan Siswa

\begin{tabular}{llll}
\hline No & $\begin{array}{c}\text { Kegiatan } \\
\text { Pembelajaran }\end{array}$ & Keterlibatan Siswa & Presentase \\
\hline 1. & Siklus I & 13 & 46 \\
2. & Siklus II & 26 & 92 \\
\hline
\end{tabular}

Dari tabel di atas dapat digambarkan dalam diagram sebagai berikut :

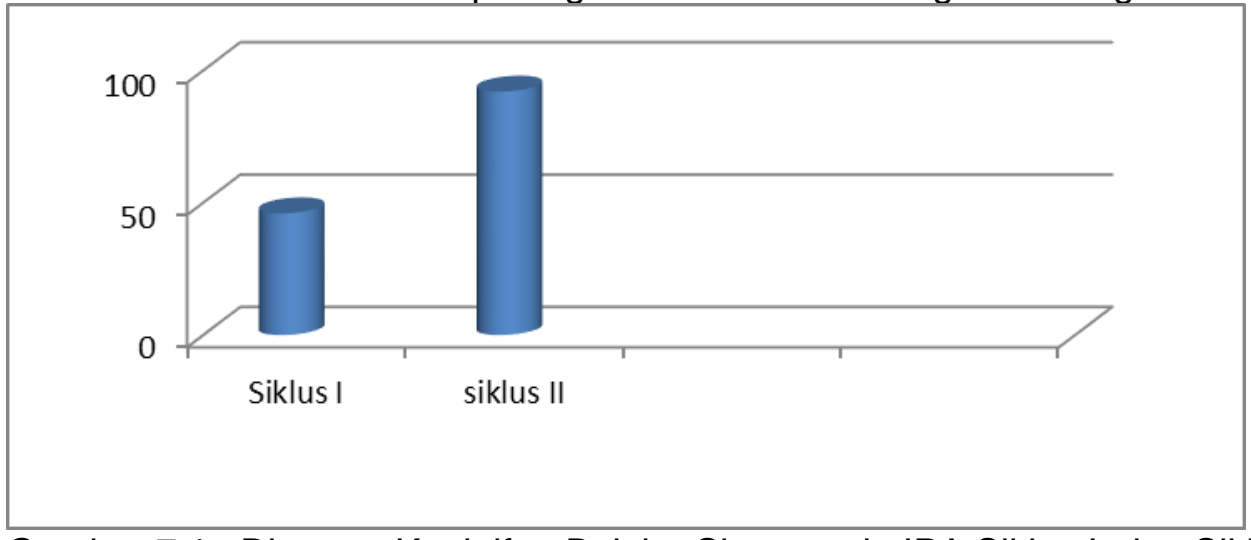

Gambar 7.1. Diagram Keaktifan Belajar Siswa pada IPA Siklus I, dan Siklus II Dari tabel dan gambar di atas dapat disimpulkan bahwa : (1) Pada siklus I siswa keterlibatan siswa dalam pembelajaran mencapai 13 siswa dari 28 siswa (46\%), (2) Pada siklus II siswa keterlibatan siswa dalam pembelajaran mencapai 26 siswa dari 28 siswa (92\%) 
Peningkatan hasil belajar peserta didik pada materi menganalisis hubungan ekosistem dan jarring jaring makanan dilingkungan sekitar diukur dengan menggunakan teknik tes hasil belajar dengan instrument lembar soal evaluasi. Teknik pengumpulan data hasil belajar peserta didik diterapkan disetiap pertemuan setelah dilakukan proses pembelajaran. Aspek yang diukur yaitu aspek kognitif atau pengetahuan yang terdiri dari mengingat (C1), memahami (C2), mengaplikasi (C3), dan menganalisis (C4) yang diukur berdasarkan hasil evaluasi setelah mengikuti pembelajaran dengan penggunaan model problem based learning pada materi menganalisis hubungan komponen ekosistem

Penggunaan model problem based learning dalam pembelajaran tematik dapat meningkatkan hasil belajar peserta didik di kelas V SDN Lomanis 01 Cilacap secara signifikan. Pada hasil Penilaian sebelumnya terdapat 7 dari 28 peserta didik yang belum mencapai KKM dengan persentase ketuntasan hasil belajar hanya $25 \%$. Setelah dilakukan tindakan, persentase ketuntasan hasil belajar pada siklus I meningkat menjadi $43 \%$. Pada siklus II terjadi peningkatan kembali pada pertemuan pertamamenjadi 92\%. Berdasarkan hasil di atas, rata- rata ketuntasan hasil belajar pada siklus I sebesar $43 \%$ dan siklus II sebesar $92 \%$. Pada siklus I pertemuan pertama belum mencapai indikator kinerja penelitian yang ditetapkan. Hasil belajar pada siklus I pertemuan kedua telah mencapai indikator kinerja penelitian dan terus meningkat pada siklus II. Pada siklus II pertemuan kedua, ketuntasan hasil belajar Informatika peserta didik telah mencapai $92 \%$ dengan KKM 70 sehingga pelaksanaan tindakan dapat dihentikan.

Berdasarkan analisis hasil belajar peserta didik setelah pelaksanaan tindakan, dapat diambil kesimpulan bahwa penggunaan metode Tutor Sebaya dapat meningkatkan hasil belajar tematik pada materi menganalisi hubungan komponen ekosistem . Hal ini sesuai dengan hasil penelitian yang dilakukan oleh Resty Adelia Novitasari yang membuktikan bahwa. menggunakan pendekatan Problem Based Learning dikarenakan pendekatan ini dapat meningkatkan hasil kreativitas dan hasil belajar siswa Hasil penelitian ini juga memperkuat pendapat Serly Medianita Manobe dan Krisma Widi Wardani bahwa melalui model Problem Based Learning dalam Pembelajaran IPA dapat meningkatkan kreativitas belajar siswa

\section{SIMPULAN}

Berdasarkan hasil penelitian dan uraian pembahasan maka dapat diambil simpulan sebagai berikut.

Penggunaan model problem based learning untuk meningkatkan hasil belajar siswa pada materi menganalisis hubungan komponen ekosistem kelas $\mathrm{V}$ SDN LOMANIS 01 Cilacap Tahun Pelajaran 2020/2021 dilaksanakan dengan langkahlangkah

(1) Peserta didik memperhatikan penjelasan guru terkait tujuan pembelajaran, media yang digunakan, serta mengenalkan masalah dan memotivasi untuk mengenali masalah mencari solusinya

(2) Menglompokan peserta didik ke dalam beberapa kelompok serta memberikan bimbingan terkait pemecahan masalah yang telah diberikan 
SHEs: Conference Series 3 (3) (2020) 371 - 377

(3) Peserta didik di ajak untuk menemukan informasi dari berbagai sumber, melakukan penyelidikan dan pemecahan masalah

(4) Peserta didik membuat rencana laporan yang akan disampaikan, berikut dengan dokumentasi yang di rancang dengan model sesuai krativitas masingmasing

Penggunaan model problem based learning dapat meningkatkan hasil belajar siswa pada materi menganalisi komponen ekosistem di kelas V SD Negeri Lomanis 01 Cilacap tahun pelajaran 2020/2021 yang dibuktikan dengan rata-rata ketuntasan hasil belajar peserta didik pada siklus I sebesar $43 \%$ dan meningkat menjadi $92 \%$ pada siklus II.

\section{DAFTAR PUSTAKA}

Ibrahim Muslimin dkk. 2005. Pembelajaran Kooperatif. Surabaya: Unesa University Pres

Kurniasih, Imas dan Berlin Sani. 2015. Ragam Pengembangan Model Pembelajaran. Jakarta: Kata Pena

Suprapto Tommy. 2009. Pengantar Teori \& Manajemen Komunikasi. Jakarta: Medpress.

Mudini . 2009 Pembelajaran Berbicara. Jakarta: DEPDIKNAS

Sari, Linda. 2017. Peningkatan Keterampilan Berbicara Dengan Menggunakan Model Pembelajaran Kooperatif Think Pair Share Pada Mata Pelajaran Bahasa Indonesia SiswaKelas V Di MIN Lhoknga Aceh Besar. Universitas Islam Negeri Ar-Raniry : Aceh

Saddhono, Kundharu dan St. Y. Slamet. 2012. Meningkatkan Keterampilan Berbahasa Indonesia (Teori dan Aplikasi). Bandung: Karya Putra Darwati

Saputra Yudha M \& Rudyanto. 2005. Pembelajaran Kooperatif untuk Meningkatkan Keterampilan Anak Tk.Jakarta:DepDiknas Dikti, Direktorat P2TK2PT

Suhartono. (2005). Pengembangan Keterampilan Bicara Anak Usia Dini. Jakarta : Departemen Pendidikan Nasional

Tarigan, Henry Guntur. 2008. Berbicara Sebagai Suatu Keterampilan Berbahasa. Bandung:Angkasa

Yuniarti, Hanifah. 2013. Penerapan Model Think Pair Share dengan Video Pembelajaran 